\title{
ENERGETYKA JĄDROWA JAKO ALTERNATYWNE ŹRÓDŁO WYTWARZANIA ENERGII W CHINACH
}

\begin{abstract}
Celem artykułu jest omówienie i ocena perspektyw rozwoju energetyki jądrowej w Chinach, jako alternatywnego źródła wytwarzania energii. Główną tezą artykułu jest stwierdzenie, że sektor produkcji energii atomowej w Chinach potencjalnie ma duże możliwości rozwoju. Wynika to z faktu zmiany w podejściu władz komunistycznych do rozwoju przemysłowego, poprzez coraz poważniejsze uwzględnianie oddziaływania na środowisko naturalne. W kolejnych dziesięcioleciach przede wszystkim planowana jest znaczna redukcja udziału węgla w wytwarzaniu energii. Odchodzeniu w przyszłości także od innych tradycyjnych surowców energetycznych sprzyjać będzie stopniowe zmniejszanie się ich światowych rezerw. Ponieważ odnawialne źródła energii mają relatywnie małe moce produkcyjne a koszt wytwarzania energii jest wysoki, nie mogą one wypełnić pojawiającej się luki. Jedynym wystarczająco efektywnym i nieobciążającym nadmiernie środowiska naturalnego wyborem może być energetyka jądrowa. Wymaga to jednak poprawy otoczenia instytucjonalnego i organizacyjnego sektora, skutecznej polityki informacyjnej wobec społeczeństwa i dbania o najwyższe standardy bezpieczeństwa. Chiny muszą także zapewnić sobie dostęp do stabilnych źródeł paliwa jądrowego. Mają im to zagwarantować długoterminowe kontrakty z dostawcami z różnych części świata. Rozwój energetyki jądrowej jest ważnym elementem zarządzania bezpieczeństwem energetycznym Chin. W ostatnich latach prawie cały globalny wzrost produkcji energii jądrowej przypada na Chiny. Wraz z rozwojem rodzimej technologii jądrowej perspektywicznie Chiny mogą również stać się jej ważnym eksporterem.
\end{abstract}

Słowa kluczowe: Chiny, źródło energii, energia jądrowa, zarządzanie bezpieczeństwem energetycznym.

\section{WPROWADZENIE}

Ze względu na konieczność znacznego wzrostu produkcji energii dla podtrzymania wysokiego tempa rozwoju gospodarczego Chińska Republika Ludowa (ChRL) stoi przed wieloma problemami. Przede wszystkim musi na bieżąco zwiększać import tradycyjnych surowców energetycznych, głównie ropy naftowej i gazu ziemnego o dostęp, do których rywalizują z innymi mocarstwami. Równie ważne są kwestie ekologiczne, w tym wzrastające skażenia powietrza dwutlenkiem węgla i negatywnymi tego następstwami. $\mathrm{Z}$ tych

\footnotetext{
${ }^{1}$ Dr hab. Łukasz Jureńczyk, Instytut Nauk Politycznych, Wydział Humanistyczny, Uniwersytet Kazimierza Wielkiego w Bydgoszczy, ul. ks. J. Poniatowskiego 12, 85-671 Bydgoszcz; e-mail: lukaszjurenczyk@ukw.edu.pl.

Łukasz Jureńczyk, DSc, PhD, Institute of Political Science, Faculty of Humanities, Kazimierz Wielki University in Bydgoszcz, ks. J. Poniatowskiego 12, 85-671 Bydgoszcz; e-mail: lukaszjurenczyk@ukw.edu.pl.
} 
powodów centralne kierownictwo Komunistycznej Partii Chin (KPCh) podejmuje działania na rzecz zwiększenia zdolności w zakresie wytwarzania energii ze źródeł odnawialnych, wody, gazu ziemnego i paliwa nuklearnego ${ }^{2}$.

Chiny jako państwo postrzegane są za główne zagrożenie dla środowiska naturalnego. Według Jareda Diamonda osiągnięcie przez Chińczyków standardu życia społeczeństw pierwszego świata będzie się wiązało z podwojeniem światowego zużycia surowców i dramatycznym pogorszeniem stanu środowiska naturalnego w skali globalnej. Ostrzega on między innymi, że jeśli utrzymane zostaną obecne trendy, to już w 2050 r. Chiny będą odpowiedzialne za $40 \%$ światowej emisji $\mathrm{CO}_{2}$ do atmosfery ${ }^{3}$. Aby kontrolować i zahamować to negatywne zjawisko w Chinach utworzono Ministerstwo Ochrony Środowiska (Ministry for Environmental Protection). Odpowiedzialne jest ono za kontrolę skażenia powietrza i wody, ale także za bezpieczeństwo wytwarzania energii atomowej ${ }^{4}$.

W 2014 r. w Chinach aż 68\% dostarczanej energii pochodziło z węgla. Zgodnie z zaleceniami World Energy China Outlook (WECO) tego samego roku postulowano rezygnację ze strategii, w której rozwijano w Chinach produkcję przemysłową nie zważając na negatywne tego konsekwencje, na rzecz strategii rozwoju przyjaznej środowisku. Według WECO wykorzystanie węgla do produkcji energii w Chinach powinno do 2035 r. spaść do $48 \% \%^{5}$. Ten znaczny poziom redukcji wydaje się być możliwy do osiągnięcia zważywszy, że już w 2016 r. udział węgla w produkcji energii wyniósł 62,4\%, czyli prawie tyle ile zakładano na rok $2020(62 \%)^{6}$.

Coraz więcej problemów jest również z poszukiwaniem i dywersyfikacją rynków dostaw surowców energetycznych. W niewielkim stopniu dotyczy to węgla, którego zarówno światowe, jak i chińskie rezerwy są znaczne. Ponadto, jak zauważono powyżej, Chiny inicjują politykę ograniczania spalania tego surowca ze względu na jego szkodliwość dla środowiska naturalnego. Znacznie większe problemy mogą się pojawić z długookresowym dostępem do ropy naftowej i gazu zimnego, których złoża stopniowo będą się wyczerpywały. Cena tych surowców może rosnąć nie tylko ze względu na malejącą podaż, ale także na konieczność pozyskiwania ich z niżej położonych i trudniej dostępnych źródeł.

\section{PRODUKCJA I KONSUMPCJA ENERGII}

Między 2006 a 2016 r. na świecie nastąpił wzrost zużycia energii z 11266,7 do 13276,3 milionów ton oleju ekwiwalentnego (MTOE). W Chinach konsumpcja energii wzrosła z 1974,7 do 3053,0 MTOE. Dla porównania w Unii Europejskiej nastąpił spadek z 1830,2

2 J.J. Ewing, China, the United States and non-traditional security: low-hanging fruit or fool's gold? [w:] New Dynamics in US-China Relations Contending for the Asia-Pacific, red. L. Mingjiang, K.M. Kemburi, Routledge, London, New York 2015, s. 148.

3 J.M. Diamond, Collapse: How Societies Choose to Fail or Succeed, Penguin Books, London 2006, rozdz. 12.

${ }^{4}$ P. Andrews-Speed, China's energy needs and energy security [w:] Sino-US Energy Triangles. Resource diplomacy under hegemony, red. D. Zweig, Y. Hao, Routledge, London, New York 2016, s. 45.

${ }^{5}$ X. Xu, World Energy China Outlook 2014, Chinese Academy of Social Sciences Press, Beijing 2014, s. 4

${ }^{6}$ W. Krzyczkowski, Chiny: wegiel w opałach, http://wysokienapiecie.pl/energetyka-konwencjonalna/1267-chiny-zuzycie-wegla-maleje (dostęp: 8.11.2017 r.). 
do 1642,0 MTOE, a w Stanach Zjednoczonych spadek z 2331,3 do 2272,7 MTOE7. Wzrost globalnego zapotrzebowania na energię pochodzi głównie od państw rozwijających się notujących wysokie przyrosty Produktu Krajowego Brutto (PKB). O ile w ostatnich latach tylko na Chiny i Indie przypadała ponad połowa tego wzrostu, o tyle w państwach rozwiniętych skupionych w Organizacji Współpracy Gospodarczej i Rozwoju (Organisation for Economic Co-operation and Development - OECD) nastąpił jego spadek ${ }^{8}$.

W samym 2016 r. konsumpcja energii w Chinach wzrosła zaledwie o 1,3\%. Wzrost konsumpcji energii w dwulatce 2015-2016 był najmniejszy od dwulatki 1997-1998. Mimo to Chiny pozostały rynkiem, w którym nastąpił największy wzrost zużycia energii 16 rok z rzędu. Obniżenie dynamiki przyrostu zużycia energii wynika ze spowolnienia gospodarczego, a przede wszystkim wyraźnego spadku produkcji w najbardziej energochłonnych sektorach. Dotyczy to głównie wyrobu żelaza, stali i cementu, które odpowiadają w Chinach za prawie jedną czwartą całkowitego zużycia energii. Ograniczenie produkcji wynika zarówno ze zmniejszonego popytu na te towary, jak również strukturalnego przekształcania chińskiej gospodarki w kierunku bardziej konsumenckiej i usługowej ${ }^{9}$.

Między 2006 a 2016 r. nastąpił w Chinach wzrost konsumpcji węgla z 1454,7 do 1887,6 MTOE (szczytowy poziom w 2013 r. - 1969,1 MTOE). W 2016 r. zużyto na świecie 3732,0 MTOE węgla, co oznacza, że na Chiny przypadło 50,6\% konsumpcji. W 2016 r. Chiny ograniczyły jednak konsumpcję węgla o $1,6 \%$, co było trzecim rokiem spadku z rzędu. $\mathrm{Z}$ dostępem do węgla jest relatywnie niewielki problem, ponieważ na terytorium Chin znajduje się 21,4\% zasobów tego surowca (244010 z $1139331 \mathrm{mln}$ ton). W 2016 r. Chiny wyprodukowały 1685,7 z 3656,4 MTOE węgla, czyli przypadło na nie 46,1\% całości światowej produkcji ${ }^{10}$. Warto zauważyć, że w omawianym roku spadła produkcja węgla w Chinach o rekordowe $7,9 \%$. Tak znaczny spadek wynika między innymi z polityki restrukturyzacji i konsolidacji sektora ${ }^{11}$ oraz ograniczania wykorzystania tego wysoce szkodliwego dla środowiska naturalnego surowca energetycznego.

W latach 2006-2016 r. nastąpił w Chinach znaczny wzrost konsumpcji ropy naftowej z 7432 do 12381 tysięcy baryłek dziennie (TBD). W 2016 r. na świecie zużyto 96558 TBD ropy, co oznacza, że na Chiny przypadło 12,8\% konsumpcji. W 2016 r. w Chinach znajdowało się 25,7 tys. mln baryłek ropy naftowej, co stanowiło zaledwie 1,5\% światowych złóż szacowanych na 1706,7 tys. mln baryłek. W 2016 r. Chiny wyprodukowały 3999 TBD ropy naftowej, z 92150 TBD wyprodukowanych na świecie, co stanowiło zaledwie 4,3\% światowej produkcji. Z tego względu w latach 2006-2016 nastąpił wzrost importu ropy naftowej do Chin z 3883 TBD do 9216 TBD $^{12}$. Oznacza to, że Chiny importują prawie trzy czwarte konsumowanej ropy naftowej, a udział ten systematycznie wzrasta w stosunku do poziomu rodzimej produkcji.

\footnotetext{
7 BP Statistical Review of World Energy, June 2017, s. 8, https://www.bp.com/content/dam/ bp/en/corporate/pdf/energy-economics/statistical-review-2017/bp-statistical-review-of-worldenergy-2017-full-report.pdf (dostęp: 2.11.2017 r.).

8 BP Energy Outlook. 2017 Edition, s. 13, https://www.bp.com/content/dam/bp/pdf/energy-economics/energy-outlook-2017/bp-energy-outlook-2017.pdf (dostęp: 8.11.2017 r.).

9 BP Statistical Review..., s. 2-3.

10 Ibidem, s. 36-40.

${ }^{11}$ Ibidem, s. 2, 5-6.

12 Ibidem, s. 12-25.
} 
W analogicznej dekadzie w Chinach nastąpił również gwałtowny wzrost konsumpcji gazu ziemnego z 59,3 do 210,3 mld $\mathrm{m}^{3}$. W 2016 r. zużyto na świecie $3542,9 \mathrm{mld} \mathrm{m}^{3}$ gazu, co oznacza, że udział Chin w konsumpcji wyniósł 5,9\%. Mimo skokowego wzrostu jest to nadal relatywnie niewielki udział w globalnym zużyciu, w porównaniu z udziałem w konsumpcji najbardziej szkodliwych dla środowiska naturalnego kopalin, tj. węgla i ropy naftowej. Jeśli chodzi o złoża gazu ziemnego to w 2016 r. w Chinach znajdowało się go zaledwie 5,4 bln $\mathrm{m}^{3} \mathrm{w}$ potwierdzonych źródłach, czyli zaledwie 2,9\% światowych złóż szacowanych na 186,6 bln $\mathrm{m}^{3}$. W $2016 \mathrm{r}$. Chiny wyprodukowały 138,4 mld $\mathrm{m}^{3} \mathrm{z} 3551,6 \mathrm{mld} \mathrm{m}^{3}$ gazu wyprodukowanego na świecie, co stanowiło zaledwie 3,9\% udziału w światowej produkcji. Z tego względu w 2016 r. Chiny zaimportowały 72,3 $\mathrm{mld} \mathrm{m}^{3}$ gazu $^{13}$.

Potencjalnie Chiny mogą posiadać relatywnie duże złoża łupkowej ropy naftowej i gazu ziemnego. Problematycznej jest jednak ich umiejscowienie, które znacząco utrudniałoby wydobycie i co za tym idzie zwiększało koszt produkcji, a także powodowało istotne zagrożenie dla środowiska naturalnego. Należy także pamiętać, że obecna technologia wydobycia surowców z łupków polega na szczelinowaniu. Jest to o tyle problematyczne, że proces ten wymaga wykorzystania znacznej ilości wody, której są w Chinach istotne niedobory ${ }^{14}$.

W zakresie energii wodnej w latach 2006-2016 nastąpił w Chinach pokaźny wzrost produkcji z 98,6 do 263,1 MTOE. Niezmiennie utrzymywały one największy udział w światowej produkcji energii wodnej, który w 2016 r. wyniósł 28,9\%. Jeśli chodzi o źródła odnawialne, to w latach 2006-2016 nastąpił w Chinach najbardziej imponujący wzrost produkcji energii z 2,5 do 86,1 MTOE. O ile jeszcze dziesięć lat temu udział Chin w globalnej produkcji energii ze źródeł odnawialnych był znikomy, to w $2016 \mathrm{r}$. stanowił on aż $20,5 \% 15$. Tylko w 2016 r. wzrost produkcji energii słonecznej i wiatrowej Chinach wyniósł aż o 14,1\%. W omawianym roku udział Chin w globalnym wzroście wszystkich segmentów produkcji energii odnawialnej wyniósł ok. 40\%. Z tego względu w 2016 r. Chinom udało się wyprzedzić na pozycji lidera Stany Zjednoczone i tym samym stały się największym na świecie producentem energii ze źródeł odnawialnych ${ }^{16}$.

W Chinach systematycznie wzrasta także konsumpcja energii jądrowej pochodzącej z rodzimej produkcji. W 2006 r. zużycie energii jądrowej w Chinach wyniosło 12,4 MTOE, w 2007 r. 14,1, w 2008 r. 15,5, w 2009 r. 15,9, w 2010 r. 16,7, w 2011 r. 19,5, w 2012 r. 22,0, w 2013 r. 25,3, w 2014 r. 30,0, w 2015 r. 38,6, a w 2016 r. 48,2 MTOE. W 2016 r. udział Chin w globalnej konsumpcji energii jądrowej wyniósł 8,1\%. Należy podkreślić, że między 2006 a 2016 rokiem konsumpcja energii jądrowej na świecie zmalała z 635,0 do $592,1 \mathrm{MTOE}^{17}$. Oznacza to, że dynamika przyrostu konsumpcji (a zarazem produkcji) energii jądrowej jest w Chinach bardzo wysoka w stosunku do odwrotnych tendencji na świecie. Warto wspomnieć o sąsiedniej Japonii, która z ponad 10-procentowego udziału w światowym rynku obecnie prawie całkowicie zrezygnowała z pozyskiwania energii jądrowej, co jest następstwem awarii w elektrowni w Fukushimie.

\footnotetext{
13 Ibidem, s. 26-35.

14 D. Zweig, Conclusion: China's 'energy anxiety' [w:] Sino-US Energy Triangles. Resource diplomacy under hegemony, red. D. Zweig, Y. Hao, Routledge, London, New York 2016, s. 256, 260.

${ }^{15}$ BP Statistical Review..., s. 42, 44.

16 Ibidem, s. 2, 5-6.

17 Ibidem, s. 41.
} 


\section{PRZYCZYNY POSZUKIWANIA ALTERNATYWNYCH ŹRÓDEŁ ENERGII}

Dynamiczny rozwój demograficzny i gospodarczy Chin powoduje wiele negatywnych konsekwencji dla środowiska naturalnego. Jedną z nich jest smog, który znacząco obniża jakość życia mieszkańców. Z tego względu spalanie tradycyjnych paliw kopalnych, w tym głównie węgla, ale także ropy naftowej, staje się rozwiązaniem przestarzałym i zbytnio obciążającym środowisko. Najlepszym remedium wydaje się produkcja czystej energii odnawialnej, takiej jak energia wiatrowa, czy słoneczna, jednak barierą są znaczne koszty jej wytwarzania. Dobrym rozwiązaniem mogłaby być również energia wodna, jednak problemem są jej ograniczone zasoby. Realną alternatywą dla kopalin staje się więc rozwój sektora produkcji energii nuklearnej. W przyszłości, obok energii z gazu ziemnego, źródeł odnawialnych i hydroenergii, może ona mieć główny udział w przyjaznej środowisku energetyce Chin.

Między 2006 a 2016 rokiem w Chinach skokowo wzrosła emisja dwutlenku węgla z 6661,6 do 9123,0 mln ton. Szczytowy był rok 2014, w którym Chiny wyemitowały do atmosfery 9224,1 mln ton $\mathrm{CO}_{2}$. Dla porównania na świecie między 2006 a 2016 rokiem emisja dwutlenku węgla wzrosła z 29430,1 do 33432,0. Oznacza to, że w 2016 r. udział Chin w światowej emisji $\mathrm{CO}_{2}$ wyniósł $27,3 \%^{18}$. Pozytywne jest, że w latach 2015-2016 zanotowano w Chinach niewielki spadek emisji dwutlenku węgla. Jest to przełom, ponieważ przez wcześniejszą dekadę nastąpił wzrost jego emisji o ponad $40 \%$. Wynika to ze słabszego wzrostu gospodarczego, przekształceń strukturalnych gospodarki w kierunku rozwoju sektorów mniej energochłonnych, większej efektywności energetycznej i ograniczania produkcji energii węglowej. Pierwszy z czynników ma charakter koniunkturalny i w okresie prosperity może nastąpić ponowne odwrócenie tendencji. Trzy kolejne związane są natomiast z przyjętymi przez KPCh programami rozwoju gospodarczego.

Wraz ze wzrostem zużycia ropy naftowej i gazu ziemnego Chiny muszą poszukiwać kolejnych złóż tych surowców i dywersyfikować ich dostawy. Z czasem będzie to coraz bardziej problematyczne, zważywszy na stopniowe wyczerpywanie się ich zapasów. Szczególnie dotyczy to ropy naftowej, którą trzeba wydobywać z coraz niżej położonych złóż, co wiąże się ze wzrostem ceny produkcji. Obecnie Chiny globalnie rywalizują z innymi mocarstwami, głównie Stanami Zjednoczonymi, o zapewnienie sobie dostępu do tego surowca. Rywalizacja ta widoczna jest zarówno w Azji, Afryce, jak i w Ameryce Południowej, a także w Arktyce, wokół której jest coraz więcej napięć międzynarodowych. Rynki surowców energetycznych narażone są na koniunkturalne znaczne wahania cen. Przykładowo między 2003 a 2008 r. cena baryłki ropy wzrosła z ok. 30 do ok. 150 dol. ${ }^{19}$ Wywołane było to głównie tzw. szokiem naftowym, czyli niepewnością co do stabilności dostaw z Zatoki Perskiej w związku z destabilizacją sytuacji w regionie wywołaną interwencją zbrojną w Iraku. Mimo okresowego załamania się koniunktury na rynku ropy naftowej, związanego z ograniczeniem zamówień na początku kryzysu gospodarczego, od 2009 r. cena ropy znów zaczęła wzrastać. Również cena gazu ziemnego ulega istotnym wahaniom. Przykładowo w Unii Europejskiej w sierpniu 2007 r. 1 tys. $\mathrm{m}^{3}$ kosztował uśredniając ok. 290 dol. w listopadzie 2008 r. ponad 570 dol., a w sierpniu 2009 r. już tylko ponad

\footnotetext{
18 Ibidem, s. 47.

${ }^{19}$ K. Kolany, Ropa „czarnym tabędziem” 2014 r., 18.12.2014, https://www.bankier.pl/wiadomosc/Ropa-czarnym-labedziem-roku-2014-7228026.html (dostęp: 8.11.2017 r.).
} 
210 dol. ${ }^{20} \mathrm{~W}$ związku z niepewnością na rynkach surowcowych, szczególnie w okresach dynamicznych wzrostów cen, inwestorzy zwracali się ku produkcji energii nuklearnej. Szczególnie duże zainteresowanie tym sektorem pojawiło się w Chinach.

Obecnie Chiny rozwijają trzyelementową strategię na rzecz zabezpieczenia zdolności zaspokajania potrzeb energetycznych. Po pierwsze, ograniczenie krajowej konsumpcji przez przemysł, który pochłania dwie trzecie zużywanej energii. Ma to następować między innymi przez wzrost efektywności energetycznej. Po drugie, inwestowanie w nowe i odnawialne źródła energii dla zdywersyfikowania jej źródeł, w tym w energię atomową, słoneczną, wiatrową i gazów łupkowych. Po trzecie, zabezpieczenie zewnętrznych dostaw energii ${ }^{21}$.

\section{ROZWÓJ SEKTORA PRODUKCJI ENERGII JACDROWEJ}

Wytwarzanie energii jądrowej w Chinach na większą skalę zaczęło się później niż w państwach Zachodu i sięga lat 80. XX wieku. W 1984 r. Chiny wstąpiły do Międzynarodowej Agencji Energii Atomowej (International Atomic Energy Agency - MAEA/IAEA). W przeciągu dwóch lat IAEA zbudowała w Chinach dwa centra szkolenia personelu do realizacji zadań w zakresie obsługi elektrowni atomowych. Chińskie władze podpisały również szereg umów dwustronnych dotyczących współpracy w zakresie energii atomowej, w tym z Danią, Szwajcarią, Finlandią i Norwegią. Setki chińskich naukowców zaczęto wysyłać za granice kraju, aby zapoznawali się z technologią nuklearną i gromadzili wiedzę potrzebną do rozwoju tego sektora w samych Chinach.

Dopiero w 1991 r. w Chinach zrealizowano pierwszy komercyjny projekt produkcji energii nuklearnej. Do końca 2007 r. Chiny zakończyły budowę 11 elektrowni atomowych w sześciu lokalizacjach. Ich całkowite moce produkcyjne wynosiły 9 gigawatów (GW). Stanowiło to zaledwie $1,7 \%$ krajowych mocy produkcji energii ${ }^{22}$. Na początku 2014 r. moce produkcyjne osiągnęły już $15,7 \mathrm{GW}$, a według planów do końca dekady mają wynieść między 50 a $58 \mathrm{GW}^{23}$. W 2030 r. poziom ten ma przekroczyć aż $170 \mathrm{GW}$, co ma stanowić udział energii jądrowej w całości wytwarzanej w Chinach energii na poziomie ok. $6 \%{ }^{24}$.

${ }^{20}$ Ceny gazu w Unii Europejskiej, 25.08.2010, http://weglowodory.pl/ceny-gazu-w-unii-europejskiej/ (dostęp: 8.11.2017 r.).

21 Y. Hao, D. Zweig, Introduction: Sino-US energy competition in resource rich states [w:] Sino-US Energy Triangles. Resource diplomacy under hegemony, red. D. Zweig, Y. Hao, Routledge, London, New York 2016, s. 3.

22 X. Xu, Nuclear energy in China: Contested regimes, „Energy” 33(8) (2008), s. 1197-1205, za: D. Zha, Debating Energy Security in China: Ideas and policy options [w:] China's Global Quest for Resources. Energy, Food and Water, red. F. Wu, H. Zhang, Routledge, London, New York 2017, s. 53.

${ }^{23}$ X. Xu, China Energy Outlook 2020, Washington 2014, s. 7, https://www.eia.gov/conference/2014/pdf/presentations/xu.pdf, (dostęp: 2.11.2017 r.); Reuters Staff, China seen buying Westinghouse reactors for $\$ 24$ billion nuclear energy projects, „Reuters”, 21.04.2014, https://www.reuters.com/article/china-nuclear/china-seen-buying-westinghouse-reactors-for-24billion-nuclear-energy-projects-idUSL3N0ND1GS20140421 (dostęp: 8.11.2017 r.).

${ }^{24}$ X. Xu, China Energy Outlook (2015-2016), s. 6, https://www.ief.org/_resources/files/snippets/chinese-academy-of-social-sciences-cass/world-energy-china-outlook-interim-report.pdf (dostęp: 2.11.2017 r.). 
Oznaczałoby to, że Chiny stałyby się przed $2030 \mathrm{r}$. liderem produkcji energii atomowej, wyprzedzając Stany Zjednoczone i Francję ${ }^{25}$.

Relatywnie dynamiczny rozwój sektora energii jądrowej na świecie trwał do 2011 r., kiedy nastąpił wypadek w elektrowni Fukushima Daichi w Japonii. Katastrofa w Fukushimie z 11 marca 2011 r. znacząco wpłynęła na postrzeganie elektrowni jądrowych w kontekście ich bezpieczeństwa. Awaria była konsekwencją tsunami wywołanego przez podwodne trzęsienie ziemi o sile 8,9 w 9-stopniowej skali Richtera ${ }^{26}$. Klęska żywiołowa doprowadziła do stopienia rdzeni trzech z sześciu reaktorów atomowych w Fukushimie. Warto nadmienić, że w reakcji na awarię w elektrowni Pekin wspomógł władze Japonii, między innymi wysyłając w miejsce katastrofy zespół ratowniczy ${ }^{27}$.

Po tragedii w Fukushimie nastąpiło zahamowanie w budowie nowych reaktorów i gruntowny przegląd realizowanych projektów, co dotyczyło także Chin. Po przeprowadzeniu wszechstronnej analizy chińskie władze zdecydowały, że dokończone zostaną projekty zatwierdzone przed incydentem. Do $2020 \mathrm{r}$. Chiny chcą osiągnąc moce produkcyjne energii nuklearnej na poziomie $70 \mathrm{mln} \mathrm{KWh}$. Jest to znaczący wzrost w stosunku do $40 \mathrm{mln} \mathrm{kWh}$ w 2015 r. Postęp ten ma być osiągnięty przy zachowaniu najwyższych standardów bezpieczeństwa $^{28}$. W ostatnich latach widoczna jest przewaga Chin nad pozostałymi państwami $\mathrm{w}$ rozwoju sektora produkcji energii nuklearnej. W przykładowej pierwszej połowie 2015 r. na 68 reaktorów budowanych na świecie, aż 28 powstawało w Chinach. Oznacza to, że w Chinach w budowie znajdowało się ówcześnie więcej reaktorów niż było funkcjonujących (tj. 20) ${ }^{29}$.

Jak wcześniej wspomniano główną zaletą rozwoju sektora produkcji energii jądrowej jest relatywnie niewielkie obciążenie środowiska naturalnego. Problemem jest wprawdzie zużyte paliwo nuklearne, jednak trwają badania nad możliwościami ponownego wykorzystania tych odpadów. Drugą korzyścią jest niższy koszt wytwarzana energii niż w przypadku źródeł odnawialnych. Za wykorzystaniem tego źródła energii przemawiają również ogromne moce produkcyjne elektrowni atomowych, jak i dostępność i prognozowana stabilność dostaw paliwa nuklearnego. $\mathrm{Z}$ tego względu chińskie władze wspierają produkcję energii atomowej poprzez zachęty finansowe. W lipcu 2013 r. wprowadzono m.in. jedną cenę na hurtową sprzedaż energii przez nowo powstające elektrownie atomowe. Cena ta ma być utrzymywana na relatywnie stabilnym poziomie.

Mimo powyższych korzyści w sektorze produkcji energii nuklearnej w Chinach istnieją jednak liczne bariery i problemy. Przede wszystkim Chiny nie podjęły decyzji dotyczącej standardu reaktora atomowego, co pogłębia niepewność technologiczną i podkopuje bezpieczeństwo operacyjne. Wybór reaktora do poszczególnych inwestycji zależy od oddziaływania międzynarodowych przedsiębiorstw, które konkurują o chiński rynek, stosując instrumenty ekonomiczne i dyplomatyczne. W rywalizacji tej uczestniczą również rodzime

${ }^{25}$ International Energy Agency, World Energy Outlook 2017. Executive Summary, s. 2, https://www.iea.org/Textbase/npsum/weo2017SUM.pdf (dostęp: 2.11.2017 r.).

${ }^{26}$ I. Sample, Japan earthquake and tsunami: what happened and why, „The Guardian” 11.03.2011, https://www.theguardian.com/world/2011/mar/11/japan-earthquake-tsunami-questions-answers (dostęp: 8.11.2017 r.).

${ }_{27}$ M. Lanteigne, Chinese Foreign Policy. An introduction, Third Edition, Routledge, London, New York 2016, s. 161.

${ }_{28}^{2}$ D. Zha, Debating Energy Security in China..., s. 53.

${ }^{29}$ Reuters Staff, China seen buying Westinghouse... 
przedsiębiorstwa chcące produkować reaktory atomowe. Ponadto istnieje wiele innych barier, w tym nieskuteczny system nadzoru, nieprzystosowana siła robocza, niewystarczające zaangażowanie sektora publicznego w inwestycje, niewystarczające zdolności w zakresie badań i rozwoju sektora. Te słabości instytucjonalne i organizacyjne powodują, że nadal nie jest pewnym, czy w przyszłości sektor produkcji energii atomowej będzie mógł się dynamicznie i swobodnie rozwijać ${ }^{30}$.

Należy pamiętać, że korzystanie z reaktorów jądrowych budzi części społeczeństwa obawy o możliwość wystąpienia awarii i przez to skażenia środowiska naturalnego. Obawa ta znacząco wzrosła po wspomnianej katastrofie w elektrowni Fukushima w Japonii. Zwrot ku znacznie większemu poleganiu na energii atomowej może więc natrafić na poważniejszy opór ze strony coraz bardziej świadomego ekologicznie społeczeństwa Chin. Ostatnie lata pokazują, że KPCh zaczyna liczyć się z głosem społeczeństwa w kwestii ochrony środowiska. Opór społeczny powstrzymał m.in. władze przed budową zakładów chemicznych w przynajmniej pięciu miastach w południowych Chinach, w tym w Kunming, Ningbo i Xiamen, jak również budową elektrowni węglowych w Haimen i Shantou w prowincji Guangdong ${ }^{31}$. Problemu tego można jednak uniknąć dzięki skutecznej polityce informacyjnej rządu i wdrażaniu najbardziej zaawansowanych systemów bezpieczeństwa. To samo tyczy się składowania odpadów nuklearnych.

\section{BUDOWA NOWYCH REAKTORÓW ATOMOWYCH I POZYSKIWANIE PALIWA NUKLEARNEGO}

W kontekście budowy w Chinach nowoczesnych reaktorów atomowych szczególnie ważna miała być współpraca ze Stanami Zjednoczonymi. W 1997 r. Pekin złożył przyrzeczenie zakończenia współpracy w obszarze nuklearnym z Iranem. Miało to prowadzić do zahamowania irańskiego programu atomowego, którego celem było wejście przez to państwo w posiadanie głowicy jądrowej. W zamian Waszyngton obiecał umożliwienie amerykańskim przedsiębiorstwom sprzedaż sprzętu i technologii potrzebnych do pozyskiwania przez Chiny energii jądrowej32. Tego roku prezydenci Jiang Zemin (03.1993 r. - 03.2003 r.) i Bill Clinton (01.1993 r. - 01.2001 r.) podpisali list intencyjny w sprawie pokojowej wspó1pracy w zakresie użycia technologii nuklearnej (Agreement of Intent on Cooperation Concerning Peaceful Uses of Nuclear Technology) ${ }^{33}$. Porozumienie to pozwoliło na transfer cywilnych technologii jądrowych z USA do ChRL.

W 2006 r. jedno z najstarszych i najbardziej uznawanych na świecie przedsiębiorstw produkujących reaktory atomowe - mające siedzibę w Pensylwanii w Stanach Zjednoczonych - Westinghouse Electric zostało zakupione przez japońską spółkę Toshiba Corp. Tego samego roku zdecydowano, że opracowany przez nią nowoczesny projekt reaktora AP1000

30 Y. Zhou, C. Rengifo, P. Chen, J. Hinze, Is China ready for its nuclear expansion?, „Energy Policy” 39(2) (2011), s. 771-781, za: D. Zha, Debating Energy Security in China..., s. 54.

${ }^{31}$ D. Zweig, Conclusion: China's 'energy anxiety'..., s. 260.

32 J. Mann, About Face: A History of America's Curious Relationship with China, from Nixon to Clinton, Vintage Books, New York 2000, s. 353-358.

${ }^{33}$ Agreement of Intent on Cooperation Concerning Peaceful Uses of Nuclear Technology, Washington, 29.10.1997, https://energy.gov/sites/prod/files/pi_iec_local/098b7ef980003cf9.pdf (dostęp: 8.11.2017 r.). 
będzie mógł zostać sprzedany do ChRL. W 2007 r. Westinghouse Electric podpisało kontrakt z China's State Nuclear Power Technology Corp. (SNPTC). Obejmowała ona budowę dwóch pierwszych jednostek AP1000 na świecie, tj. dla elektrowni na wyspie Sanmen $\mathrm{w}$ prowincji Zhejiang w południowo-wschodnich Chinach. Pierwszy z reaktorów miał zostać uruchomiony w 2013 r., a drugi w 2014 r. Zgodnie z umową budowa czterech kolejnych jednostek zakontraktowana została dla elektrowni Haiyang we wschodniej prowincji Shandong ${ }^{34}$. W praktyce budowa pierwszych reaktorów w Sanmen i Haiyang uległa znacznym opóźnieniom. Wynikły one $\mathrm{z}$ koniecznych wprowadzenia zmian projektowych, problemów z zaopatrzeniem i zaostrzonych rygorów bezpieczeństwa po katastrofie w Fukushimie. Uruchomienie pierwszego z nich przesunięto na lato 2017 r. Najbardziej pozytywny scenariusz zakłada uruchomienie do końca 2017 r. dwóch reaktorów w Sanmen i dwówch w Haiyang ${ }^{35}$. Testy bezpieczeństwa i efektywności ekonomicznej tych pierwszych reaktorów są kluczowe dla dalszych inwestycji opartych o reaktor AP1000 ${ }^{36}$. Mimo komplikacji w 2014 r. prowadzono rozmowy i podpisano umowę na zakup kolejnych ośmiu reaktorów AP1000. Koszt elektrowni ze sprzętem i usługami miał wynieść 24 mld dol. Reaktory te mają być zbudowane w czterech lokalizacjach, w tym w Sanmen oraz w Haiyang. Rozpoczęto również rozmowy na budowę kolejnych czterech reaktorów w Xudapu w północno-wschodniej prowincji Liaoning i Lufeng w południowej prowincji Guangdong ${ }^{37}$.

Jeszcze poważniejsze problemy z budową reaktorów AP1000 w Stanach Zjednoczonych, postawiły spółkę Westinghouse Electric na skraju bankructwa. Jej ewentualna sprzedaż nie powinna jednak negatywnie odbić się na budowie reaktorów w Chinach. Projekt AP1000 jest o tyle ważny, że może on stanowić podstawę dla rozwoju chińskiej technologii nuklearnej. Perspektywicznie reaktory AP1000 mają być budowane w Chinach w ramach samodzielnego projektu chińskiego. Z obecnie planowanej w Chinach budowy 41 reaktorów, ponad połowa ma stanowić reaktory $\mathrm{AP} 1000^{38}$.

Należy zauważyć, że decyzja o sprzedaży przez Westinghouse Electric AP1000 została podjęta dopiero, gdy stała się ona własnością Toshiba Corp. Stany Zjednoczone są niechętne do transferu zaawansowanych technologii nuklearnych do Chin. Wynika to z faktu, że relacje między USA a ChRL wypaczone są zimnowojennym myśleniem. Waszyngton nie chce wspierać technologicznie swojego głównego rywala w walce o pozycję hegemoniczną. Warto nadmienić, że Chiny chciałyby zakupywać tego rodzaju technologie na preferencyjnych warunkach wynikających z Protokołu z Kioto w sprawie przeciwdziałania globalnemu ociepleniu. Stany Zjednoczone z kolei w najlepszym wypadku gotowe są je sprzedawać na warunkach komercyjnych. Inne podejście niż Stany Zjednoczone prezentuje w tej materii Japonia. Jest ona znacznie bardziej elastyczna we współpracy z Chinami w obszarze cywilnych technologii jądrowych. Wynika to przede wszystkim z bliskości

${ }^{34}$ S. Patel, China Begins Construction of World's First AP1000 Reactor, 1.06.2009, http:// www.powermag.com/china-begins-construction-of-worlds-first-ap1000-reactor/ (dostęp: 11.11. 2017 r.).

35 S. Patel, New Construction Milestones for AP1000 Units, 1.03.2017, http://www.powermag. com/new-construction-milestones-ap1000-units/ (dostęp: 11.11.2017).

${ }^{36}$ S. Stepczyński, A. Guo, This Chinese Nuclear Plant's Success Is Critical to Westinghouse's Future, 26.04.2017, https://www.bloomberg.com/news/articles/2017-04-26/nuclear-reactor-treasureseen-buried-in-wreck-of-westinghouse (dostęp: 11.11.2017).

${ }^{37}$ Reuters Staff, China seen buying Westinghouse...

${ }^{38}$ S. Stepczyński, A. Guo, This Chinese Nuclear... 
terytorialnej między państwami i co za tym idzie - znacznie poważniejszego oddziaływania powietrza skażonego przez chiński przemysł na Japończyków ${ }^{39}$.

Odrębną kwestię stanowi dostęp do surowca wykorzystywanego w produkcji energii jądrowej. Wiodącym światowym producentem uranu jest Kazachstan, wyprzedzający w tym obszarze Kanadę i Australię. Uprzywilejowaną pozycję na kazachskim rynku uranu ma Rosja, ze względu na jej historyczny wkład w rozwój sektora w czasach sowieckich. Przykładowo w 2006 r. Moskwa i Astana podpisały bilateralny program o współpracy w cywilnym sektorze energii atomowej, w ramach którego znalazły się porozumienia o wartości ok. 10 mld dol. Ze względu na wzrastające zapotrzebowanie ChRL na paliwo jądrowe dynamicznie rozwija się współpraca między Pekinem a Astaną. W 2000 r. kazachska państwowa agencja energii atomowej - Kazatomprom - podpisała kilka porozumień o współpracy z China Guangdong Nuclear Power Group (obecnie China General Nuclear Power Group - CGN) ${ }^{40}$. Dzięki tym i kolejnym umowom Chiny są obecnie niezwykle ważnym nabywcą uranu z Kazachstanu. W 2014 r. Kazatomprom poinformował, że 55\% wyprodukowanego w Kazachstanie surowca wyeksportowano właśnie do Chin ${ }^{41}$. Warto wspomnieć, że swój udział na kazachskim rynku paliwa nuklearnego mają również Stany Zjednoczone. Kazatomprom zakupił w 2007 r. od Toshiby 10\% udziałów w Westinghouse Electric i dostarcza paliwo nuklearne do amerykańskiego przedsiębiorstwa. Nie mniej jednak Stany Zjednoczone odgrywają na kazachskim rynku uranu rolę marginalną i nie mają prawie żadnego wpływu na tzw. rosyjsko-chińsko-kazachski trójkąt nuklearny ${ }^{42}$.

Chińskie projekty nuklearne dotyczą również obszaru wojskowości i przemysłu zbrojeniowego. ChRL w szybkim tempie modernizuje arsenału nuklearnego w celu zwiększenia zdolności odstraszania, jednak kwestia ta nie mieści się w obszarze omawianej problematyki. Należy jednak wspomnieć, że Chiny rozwijają projekt budowy jednego lub nawet dwóch większych lotniskowców o napędzie jądrowym i kilku łodzi podwodnych również zasilanych reaktorem jądrowym. Konstrukcje te przede wszystkim bazują na rozwijanych i unowocześnianych technologiach sowieckich ${ }^{43}$.

Warto nadmienić, że Chiny zaczynają brać udział w rozwoju energetyki jądrowej również poza granicami kraju. Chińscy robotnicy uczestniczyli między innymi w budowie elektrowni jądrowej w pakistańskiej prowincji Pendżab ${ }^{44}$. Przełomowe było podpisanie w październiku 2015 r. porozumienia z Wielką Brytanią o współfinansowaniu przez Chiny budowy w tym kraju elektrowni atomowej. Będzie to pierwsza elektrownia atomowa zbudowana w Wielkiej Brytanii od 1995 r., a w całej Unii Europejskiej od katastrofy

${ }^{39}$ M. Tai, US-China Relations in the Twenty-First Century. A question of trust, Routledge, London, New York 2015, s. 88.

${ }^{40}$ S. Peyrouse, Perspectives and limits on Sino-US competition: the Kazakhstan case study [w:] SinoUS Energy Triangles..., s. 172.

${ }^{41}$ S. Lain, China and Russia: cooperation and competition in Central Asia [w:] Chinese Foreign Policy Under Xi, red. H.T. Boon, Routledge, London, New York 2017, s. 79.

${ }^{42}$ S. Peyrouse, Perspectives and limits on Sino-US competition..., s. 172.

${ }^{43} \mathrm{M}$. Li, K. Kemburi, Z. Hongzhou, Growth of China's power: capabilities, perceptions, and practice [w:] China's Power and Asian Security, red. M. Li, K.M. Kemburi, Routledge, London, New York 2015, s. 13.

${ }^{44}$ M. Ali, Peripheral South Asian response to the growth of Chinese power: a study in dichotomous continuity, [w:] China's Power..., s. 115. 
w Fukushimie w 2011 r. Reaktor zostanie zbudowany przez francuską spółkę Électricité de France (EdF) przy wsparciu $\mathrm{CGN}^{45}$.

\section{PODSUMOWANIE I PERSPEKTYWY NA PRZYSZŁOŚĆ}

W okresie 20 lat, tj. między 2015 a 2035 r. około połowy wzrostu produkcji energii na świecie ma pochodzić ze źródeł odnawialnych, z energii jądrowej i wodnej ${ }^{46}$. W przypadku Chin w okresie tych 20 lat udział odnawialnych źródeł, energii jądrowej i wodnej w całościowej produkcji energii ma wzrosnąc z $12 \%$ do ponad $25 \%$, z czego udział energii jądrowej ma wynieść przynajmniej 7\% całości produkcji ${ }^{47}$. W 2016 r. globalna produkcja energii jądrowej wzrosła o 1,3\%. Za praktycznie cały wzrost odpowiadały Chiny, ponieważ zanotowały wtedy krajowy wzrost produkcji energii jądrowej na poziomie $24,5 \%$. Był to największy przyrost zanotowany przez jakiekolwiek państwo od $2004 \mathrm{r}^{48}$ Według ambitnych planów do $2030 \mathrm{r}$. Chiny chcą mieć 13-procentowy udział w światowej produkcji energii nuklearnej ${ }^{49}$.

Wzmożona emisja dwutlenku węgla do atmosfery będąca efektem dynamicznego rozwoju gospodarczego Chin pogłębia zjawisko efektu cieplarnianego i przyczynia się do wzrostu temperatury na świecie. Jeszcze bardziej namacalną dla przeciętnego mieszkańca Chin konsekwencją tego działania jest odczuwalny wzrost zanieczyszczenia powietrza $\mathrm{i}$ istniejący w miastach efekt smogu. $Z$ tych powodów chińskie władze zdecydowały się na zmianę podejścia do gospodarowania. Przede wszystkim wprowadzają technologie, które mają zapewnić większą efektywność wykorzystania energii. Jednocześnie zainicjowały politykę stopniowego ograniczenia produkcji energii z wykorzystaniem najbardziej uciążliwego dla środowiska surowca energetycznego, czyli węgla. Perspektywicznie liderzy KPCh muszą również brać pod uwagę stopniowe odchodzenie od innych kopalin, tj. ropy naftowej i gazu ziemnego. Wynika to z faktu ograniczonych rezerw tych surowców na świecie. Lukę tą trzeba uzupełniać innymi źródłami energii.

W związku z powyższym rozwijany jest program pozyskiwania energii ze źródeł odnawialnych. Jego koszt i ograniczone moce produkcyjne powodują jednak, że w najbliższych dekadach nie mogą one stać się głównym źródłem energii w Chinach. W tych okolicznościach energia atomowa może być więc jedynym wystarczająco efektywnym i jednocześnie nie obciążającym nadmiernie środowiska naturalnego wyborem ${ }^{50}$. Oznacza to, że sektor energii jądrowej w Chinach może w przyszłości jeszcze bardziej dynamicznie się rozwijać. Wymaga to jednak poprawy otoczenia instytucjonalnego i organizacyjnego, skutecznej polityki informacyjnej wobec społeczeństwa i dbania o najwyższe standardy bezpieczeństwa. Wraz z rozwojem rodzimej technologii jądrowej perspektywicznie Chiny mogą również stać się jej ważnym eksporterem.

45 J. Nakano, M. Melton, The UK-China Civilian Nuclear Agreement, 23.10.2015, https://www. csis.org/analysis/uk-china-civilian-nuclear-agreement (dostęp: 12.11.2017 r.).

${ }^{46}$ BP Energy Outlook..., s. 6, 15.

${ }^{47}$ Z. Hong, Energy security and US-China relations in the Asia-Pacific [w:] New Dynamics in US-China Relations Contending for the Asia- Pacific, red. L. Mingjiang, K.M. Kemburi, Routledge, London, New York 2015, s. 161.

48 BP Statistical Review..., s. 2.

${ }^{49}$ M. Tai, US-China Relations in the Twenty-First Century..., s. 83.

50 Ibidem, s. 72. 


\section{LITERATURA}

1. Ali M., Peripheral South Asian response to the growth of Chinese power: a study in dichotomous continuity [w:] China's Power and Asian Security, red. M. Li, K.M. Kemburi, Routledge, London, New York 2015.

2. Andrews-Speed P., China's energy needs and energy security [w:] Sino-US Energy Triangles. Resource diplomacy under hegemony, red. D. Zweig, Y. Hao, Routledge, London, New York 2016.

3. Diamond J.M., Collapse: How Societies Choose to Fail or Succeed, Penguin Books, London 2006.

4. Ewing J.J., China, the United States and non-traditional security: low-hanging fruit or fool's gold? [w:] New Dynamics in US-China Relations Contending for the Asia-Pacific, red. L. Mingjiang, K.M. Kemburi, Routledge, London, New York 2015.

5. Hao Y., Zweig D., Introduction: Sino-US energy competition in resource rich states [w:] Sino-US Energy Triangles. Resource diplomacy under hegemony, red. D. Zweig, Y. Hao, Routledge, London, New York 2016.

6. Hong Z., Energy security and US-China relations in the Asia-Pacific [w:] New Dynamics in US-China Relations Contending for the Asia-Pacific, red. L. Mingjiang, K.M. Kemburi, Routledge, London, New York 2015.

7. Lain S., China and Russia: cooperation and competition in Central Asia [w:] Chinese Foreign Policy Under Xi, red. H.T. Boon, Routledge, London, New York 2017.

8. Lanteigne M., Chinese Foreign Policy. An introduction, Third Edition, Routledge, London, New York 2016.

9. Li M., Kemburi K., Hongzhou Z., Growth of China's power: capabilities, perceptions, and practice [w:] China's Power and Asian Security, red. M. Li, K.M. Kemburi, Routledge, London, New York 2015.

10. Mann J., About Face: A History of America's Curious Relationship with China, from Nixon to Clinton, Vintage Books, New York 2000.

11. Peyrouse S., Perspectives and limits on Sino-US competition: the Kazakhstan case study [w:] Sino-US Energy Triangles. Resource diplomacy under hegemony, red. D. Zweig, Y. Hao, Routledge, London, New York 2016.

12. Tai M., US-China Relations in the Twenty-First Century. A question of trust, Routledge, London, New York 2015.

13. Xu X., World Energy China Outlook 2014, Chinese Academy of Social Sciences Press, Beijing 2014.

14. Xu X., Nuclear energy in China: Contested regimes, „Energy” 33(8), 2008.

15. Zha D., Debating Energy Security in China: Ideas and policy options [w] China's Global Quest for Resources. Energy, Food and Water, red. F. Wu, H. Zhang, Routledge, London, New York 2017.

16. Zhou Y., Rengifo C., Chen P., Hinze J., Is China ready for its nuclear expansion? „Energy Policy" 39(2), 2011.

17. Zweig D., Conclusion: China's 'energy anxiety' [w:] Sino-US Energy Triangles. Resource diplomacy under hegemony, red. D. Zweig, Y. Hao, Routledge, London, New York 2016. 


\section{NETOGRAFIA}

1. Agreement of Intent on Cooperation Concerning Peaceful Uses of Nuclear Technology, Washington, 29.10.1997, https://energy.gov/sites/prod/files/pi_iec_local/098b7ef980003 cf9.pdf (dostęp: 8.11.2017 r.).

2. BP Energy Outlook. 2017 Edition, https://www.bp.com/content/dam/bp/pdf/energy-economics/energy-outlook-2017/bp-energy-outlook-2017.pdf (dostęp: 8.11.2017 r.).

3. BP Statistical Review of World Energy, June 2017, https://www.bp.com/content/dam/ bp/en/corporate/pdf/energy-economics/statistical-review-2017/bp-statistical-review-ofworld-energy-2017-full-report.pdf (dostęp: 2.11.2017 r.).

4. Ceny gazu w Unii Europejskiej, 25.08.2010, http://weglowodory.pl/ceny-gazu-w-unii-europejskiej/ (dostęp: 8.11.2017 r.).

5. International Energy Agency, World Energy Outlook 2017. Executive Summary, https://www.iea.org/Textbase/npsum/weo2017SUM.pdf (dostęp: 2.11.2017 r.).

6. Kolany K., Ropa „czarnym tabędziem” 2014 r., 18.12.2014, https://www.bankier.pl/wiadomosc/Ropa-czarnym-labedziem-roku-2014-7228026.html (dostęp: 8.11.2017 r.).

7. Krzyczkowski W., Chiny: węgiel w opałach, http://wysokienapiecie.pl/energetyka-konwencjonalna/1267-chiny-zuzycie-wegla-maleje (dostęp: 8.11.2017 r.).

8. Nakano J., Melton M., The UK-China Civilian Nuclear Agreement, 23.10.2015, https://www.csis.org/analysis/uk-china-civilian-nuclear-agreement (dostęp: 12.11.2017 r.).

9. Patel S., China Begins Construction of World's First AP1000 Reactor, 1.06.2009, http://www.powermag.com/china-begins-construction-of-worlds-first-ap1000-reactor/ (dostęp: 11.11.2017).

10. Patel S., New Construction Milestones for AP1000 Units, 1.03.2017, http://www. powermag.com/new-construction-milestones-ap1000-units/ (dostęp: 11.11.2017 r.).

11. Reuters Staff, China seen buying Westinghouse reactors for $\$ 24$ billion nuclear energy projects, „Reuters”, 21.04.2014, https://www.reuters.com/article/china-nuclear/china-seenbuying-westinghouse-reactors-for-24-billion-nuclear-energy-projectsidUSL3N0ND1GS20140421 (dostęp: 8.11.2017 r.).

12. Sample I., Japan earthquake and tsunami: what happened and why, „The Guardian” 11.03.2011, https://www.theguardian.com/world/2011/mar/11/japan-earthquake-tsunamiquestions-answers (dostęp: 8.11.2017 r.).

13. Stepczyński S., Guo A., This Chinese Nuclear Plant's Success Is Critical to Westinghouse's Future, 26.04.2017, https://www.bloomberg.com/news/articles/2017-04-26/nuclear-reactor-treasure-seen-buried-in-wreck-of-westinghouse (dostęp: 11.11.2017 r.).

14. Xu X., China Energy Outlook (2015-2016), https://www.ief.org/_resources/files/snippets/chinese-academy-of-social-sciences-cass/world-energy-china-outlook-interim-report. pdf (dostęp: 2.11.2017 r.).

15. Xu X., China Energy Outlook 2020, Washington 2014, https://www.eia.gov/conference/2014/pdf/presentations/xu.pdf (dostęp: 2.11.2017 r.).

\section{NUCLEAR POWER AS AN ALTERNATIVE ENERGY SOURCE IN CHINA}

The aim of this article is to discuss and evaluate the prospects for the development of nuclear power in China as an alternative source of energy. The main thesis of the article is that the nuclear sector in China has a lot of potential for development. This is due to a change in the 
attitude of the communist authorities to industrial development, by increasingly taking into account the impact on the environment. In the coming decades, a significant reduction in the share of coal in energy production is planned above all. Going away from other traditional energy resources in the future will be determined by gradual decrease in their global reserves. Since renewable energy sources have relatively low capacity and the cost of generating electricity is high, they can't fill the gap. The only sufficiently effective and not overburdening natural environment can be nuclear power. This, however, requires an improvement in the institutional and organizational environment of the sector, an effective information policy towards society and the highest standards of safety. China also needs to secure an access to stable sources of nuclear fuel. It has to be guaranteed by long-term contracts with suppliers from different parts of the world. The development of nuclear energy is an important element of China's energy security management. In recent years, China was responsible for almost all of the global increase in nuclear energy production. With the development of domestic nuclear technology, China is likely to become an important exporter as well.

Keywords: China, source of energy, nuclear energy, nuclear reactor, energy security management.

DOI: $10.7862 / \mathrm{rz} .2018 . \mathrm{mmr} .27$

Tekst złożono do redakcji: kwiecień 2018 r.

Tekst przyjęto do druku: sierpień $2018 r$ r. 